\title{
El arcedianATO de NÁJERA, UN BENEFICIO ECLESIÁSTICO EN MANOS DE LAS OLIGARQUÍAS SALMANTINAS EN LA BAJA EDAD MEDIA
}

\author{
Luis PelÁEz Boismorand ${ }^{1}$ \\ Universidad de Strasbourg
}

Recibido: 5 de abril de 2018

Aceptado: 3 de mayo de 2018

\begin{abstract}
Resumen
El objetivo de este trabajo es abordar el caso de los beneficios eclesiásticos patrimoniales en la Baja Edad Media en Castilla. Éstos no siempre caían bajo el control de las diócesis a las que estaban vinculados, recayendo este control administrativo y económico en ocasiones en manos de ciertas oligarquías castellanas. Los arcedianatos, siendo un beneficio eclesiástico de gran interés sobre todo por sus rendimientos económicos, sirvieron en ocasiones como moneda de cambio entre poderosas familias con intereses afines. Expondremos el caso del arcedianato de Nájera, que durante casi cien años estuvo en manos de ciertas familias de las oligarquías urbanas salmantinas entre el siglo XV e inicios del siglo XVI, como un ejemplo bien documentado de este caso e intentaremos describir algunos de los catalizadores que lo han provocado.
\end{abstract}

\section{Palabras clave}

Beneficios eclesiásticos; arcedianato de Nájera; bando de San Benito; Patronato Real; catedral de Salamanca.

\begin{abstract}
In this work we examine the case of ecclesiastical office assets in Castile over the Late Middle Ages. These assets were not always controlled by the diocese to which they were attached. At times, they fell under the administrative and economic control of Castilian oligarchies. Arch-deaneries generated significant profits and were therefore the focus of strong interest. At times, powerful families linked by common interests used them as a bargaining chip. We will analyse the case of the arch-deanery of Nájera, which was held by a group of families belonging to the urban oligarchy of Salamanca for nearly a century, from the 15 th century to the beginning of the 16 th century. Our case of study constitutes a well-documented example that can help us to explain the roots of these phenomena.
\end{abstract}

\section{Keywords}

Ecclesiastical offices; Nájera arch-deanery; St. Benito's faction; Royal Patronage; Salamanca Cathedral.

1 Correo electrónico: pelaezboismorand@unistra.fr. ORCID: https://orcid.org/0000-0003-1806-2157. 


\section{Résumé}

L'objectif de cet étude est d'aborder le cas des bénéfices ecclésiastiques patrimoniaux pendant le Bas Moyen Âge en Castille. Ceux-ci ne relevaient pas toujours du contrôle des diocèses auxquels ils étaient rattachés car leur contrôle administratif et économique était dans les mains de certaines oligarchies castillanes. Les archidiaconats, étant un bénéfice de l'église très intéressant surtout par ses performances économiques, ont servi parfois comme monnaie d'échange entre les importants lignées avec des objectifs similaires. Nous raconterons le cas de l'archidiaconat de Nájera lequel, pendant presque cent ans, il a été dans les mains de certaines familles des oligarchies urbaines salmantinas entre le XVème siècle et début XVIème siècle comme un exemple très bien documenté de cela, et nous essaierons de décrire les catalyseurs qui ont stimulé cette situation.

\section{Mots clés}

Bénéfices ecclésiastiques; archidiaconat de Nájera; faction de Saint Benoit; patronage royale; cathédrale de Salamanque.

\section{Introducción}

A inicios del siglo XIII diócesis de Calahorra se consolida definitivamente como tal, disponiendo de potestad episcopal y de potestad territorial. Este hecho es parte de una estrategia de la corte de Castilla para asegurar la paz y el control de la frontera con Navarra y Aragón y esta consolidación se hace a costa del poder de los monasterios que se asentaban en esos territorios. La estrategia de Alfonso VIII tomaba el relevo a la reforma de Gregorio VII que se había basado en el regreso a la iglesia primitiva monástica. La configuración territorial de la diócesis calagurritana en la baja Edad Media, comprendía los arcedianatos de Berberiego, Calahorra, Santo Domingo de la Calzada, Álava, Vizcaya y Nájera².

Nuestro objetivo es estudiar la llegada a manos de ciertos linajes salmantinos de este último beneficio patrimonial ${ }^{3}$, el arcedianato de Nájera, su transferencia entre unos y otros miembros de estas familias que estaban adscritas al todas ellas al bando de San Benito y las lecturas que esto podría tener en términos de concurrencia de intereses y sus correspondientes expresiones. Reflexionaremos sobre las razones que podrían explicar esta singular circunstancia. Para ello nos apoyaremos en el análisis de las fuentes manuscritas de los archivos de Simancas, de la Catedral de Salamanca y del

\footnotetext{
IBÁÑEz Rodríguez, "La diócesis de Calahorra a mediados del siglo XV", p. 146. Debe aclararse desde el inicio que Nájera, una villa que requería más de dos jornadas de viaje (dos dietas) para llegar desde Salamanca, no tenía ningún nexo de ningún tipo con la diócesis salmantina.

3 Catalán Martínez, "Derecho de patronato y el régimen beneficial de la Iglesia española". Esta autora define en la p. 137 que "el derecho de patronato sobre estas instituciones [establecimientos eclesiásticos] implica la obligación de conservarlas, engrandecerlas y protegerlas. A cambio se obtiene el derecho de proponer y de nombrar a sus servidores, la percepción de una asignación económica y, muchas veces, el ejercicio de la jurisdicción”. Era implícito también el control sobre las donaciones, sobre las limosnas así como la gestión de los asuntos ante el fisco regio: la recaudación del diezmo y el pago de las tercias reales.
} 
Archivo Secreto Vaticano así como de fuentes ya editadas ${ }^{4}$. Algunas fuentes tardías, como documentación de la colección Salazar y Castro o un memorial, en ambos casos e inicios y finales del XVII, también han sido aprovechados.

\section{Una aproximación al fenómeno de los bandos en Salamanca en la Baja Edad Media}

El siglo $\mathrm{XV}$, el contexto cronológico al que vamos a referirnos, es un período marcado por divisiones las políticas en Castilla. Dos fueron los hechos que catalizaron dichas divisiones:

- Las injerencias de los infantes de Aragón en la corte castellana de Juan II.

- Las divisiones políticas relacionadas con el problema sucesorio de Enrique IV a lo que se sumaban las disputas por el control de la Orden de Santiago. El puesto de Gran Maestre estaba reservado al infante Alfonso de Ávila ${ }^{5}$, según había dispuesto su padre Juan II en su testamento.

Como es sabido, la actitud de la gran nobleza castellana en aquel siglo XV, pero también la de algunas oligarquías urbanas, ejercía una fuerte influencia en las dinámicas políticas de la corte castellana. Los validos, personajes influyentes en la voluntad de los dos reyes mencionados, tienen asimismo un papel destacado en esta situación. Nos referimos a Álvaro de Luna en el caso de Juan II y al marqués de Villena y a Beltrán de la Cueva en el caso de Enrique IV. No le corresponde a este trabajo hacer una revisión de estos catalizadores y problemáticas pero en cambio sí que trataremos de abordar sus consecuencias en lo que se refiere a la formación de bandos y parcialidades, un fenómeno frecuente en ese momento en Castilla. En Salamanca también sucede lo propio y las divisiones y los diferentes posicionamientos se hacen patentes a lo largo del siglo XV. Dos bandos configuraron en Salamanca estas parcialidades. El bando de San Benito y el bando de Santo Tomé. Sus ideales y objetivos se podrían explicar con la máxima simplificación si lo deseamos: partidarios o detractores de las injerencias de los infantes de Aragón en la corte del joven Juan II, y las discusiones por la sucesión de la corona del cedente Enrique IV hacia Juana la Beltraneja o hacia su hermanastra la infanta Isabel con la intervención de los validos Beltrán de la Cueva y el marqués de Villena. En esta última cuestión, las familias salmantinas partidarias de la sucesión del trono de Castilla

\footnotetext{
${ }^{4}$ ASV: Archivo Secreto Vaticano; ACS: Archivo Capitular de Salamanca; AGS: Archivo General de Simancas y RAH: Real Academia de la Historia. Registros. Reg. Lat.: Registro Lateranense; RGS: Registro General del Sello; Reg. Suppl.: Registro de Súplicas; QC: Quitaciones de Corte; CCa: Cámara de Castilla y SYC: Colección Salazar y Castro.

5 Son muchas las denominaciones que podemos encontrar en la bibliografía del infante Alfonso a partir de la Farsa de Ávila: Alfonso de Ávila, Alfonso el doceno, el rey niño Alfonso, etc. En este texto nos referiremos a él como rey Alfonso de Ávila.
} 
en la figura del infante Alfonso (de Ávila) y una vez que éste muere prematuramente en Cardeñosa en 1468, de la infanta Isabel, son las pertenecientes al bando de San Benito ${ }^{6}$. Así, los intereses políticos y económicos y, en consecuencia, la obtención, el mantenimiento y la reproducción del poder son los promotores principales en la creación de las parcialidades. En el caso de los linajes salmantinos, muy bien estudiado por Clara I. López, el reparto de poder estaba fuertemente mediatizado por los casamientos que eran la mejor manera de mantener y de reproducir el poder social, practicando una suerte de endogamia en la comunidad.

El caso estudiado en mi tesis del linaje de los Paz, una familia de la oligarquía salmantina perteneciente al bando de San Benito, es paradigmático. Tal como podemos claramente ver en el anexo a continuación los enlaces matrimoniales a lo largo del siglo XV de los Paz, "señores de los Corrales", ya sean los matrimonios de conveniencia ya los concertados, lo fueron casi únicamente entre familias del mismo bando ${ }^{7}$. No son sutiles las diferencias entre estas formas de definir el modo de acceso al matrimonio entre las oligarquías. Normalmente el matrimonio concertado buscaba asegurar la inclusión social de una hija. En esta situación que exponemos de la familia Paz, esto afectaba principalmente a las hijas de altos clérigos y era un acto pactado entre los suegros. El matrimonio de conveniencia no pretendía otra cosa que asegurar, preservar y reproducir el poder social adquirido.

Los Paz, Anaya, Enríquez, Nieto, Maldonado, Fontíveros y Maldonado militaron todos en el mismo bando, el de San Benito ${ }^{8}$.

\section{Ilustración 1}

\begin{tabular}{|c|c|}
\hline Sancho Pérez de Paz & María Álvarez de Anaya \\
\hline Antón Sánchez de Paz & Juana Enríquez \\
\hline Antón de Paz & Guiomar Álvarez Nieto \\
\hline Luis Álvarez de Paz & Teresa Rodríguez Maldonado \\
\hline Antón de Paz & \\
\hline & María Gutierrez de Fontíveros \\
\hline Lorenzo de Paz & Juana Bonal Maldonado \\
\hline
\end{tabular}

\footnotetext{
Este bando se mostró contrario a las injerencias de los infantes de Aragón en la corte castellana del joven Juan II. Para una aproximación al tema, el caso del linaje de los Paz de Salamanca su pertenencia al bando de San Benito y los planteamientos políticos de este bando, véase la tesis doctoral PelÁez Boismorand, Poder y movilidad social.

7 Solís, Memorial de la Calidad i Serviçios de Don Cristóbal Alfonso de Solís i Enríquez, pp. 46v-49v; SÁnchez VAQUero, Linajes de Salamanca y RAH, SYC diversas tablas genealógicas de los Paz de Salamanca: SYC, (D-27), ff. 182r-182v y SYC, (D-25), f. 81v.

8 Monsalvo Antón, Torres, tierras, linajes, p. 202, cita a pie 88 que refiere la adscripción de los linajes salmantinos a uno y otro bando que se puede encontrar en el poema heráldico Triunfo Raimundino.
} 
Una expresión del control del poder social y económico que practicaron entre sí y para sí las familias del mismo bando, fue el dominio que el bando de San Benito tenía sobre la catedral. La presencia de apellidos del bando de San Benito es notoria y mayoritaria entre las dignidades de finales del siglo XIV y todo el siglo XV, el período que nos ocupa. Como muy gráficamente explica la Dra. Lop Otín ${ }^{9}$, tenemos que ver la catedral como una empresa que genera numerosa mano de obra para los artesanos y obreros de la ciudad, lo que explica su importante influencia social. El mantenimiento diario de la catedral obligaba a disponer de barrenderos, campaneros, lampareros, etc. y artesanos canteros bien adiestrados para las labores de conservación de la fábrica. Los capitulares, como miembros de esta empresa, pertenecían normalmente a la aristocracia local y, tal como ya hemos señalado, participaban en los asuntos de su ciudad posicionándose también en las intrigas y en las parcialidades tan comunes de las ciudades de la Castilla Trastámara. La propia Dra. Lop Otín se refiere a ellos como... la aristocracia eclesiástica por encima del clero parroquial y monástico ... ${ }^{10}$. En el caso de la catedral de Salamanca, de catorce racioneros, canónigos y otras dignidades tales como deanes cuyos apellidos que se pueden poner en relación con el bando de San Benito o con el bando de Santo Tomé, trece lo eran de familias del bando de San Benito ${ }^{11}$.

Otras informaciones que también podríamos ofrecer sobre el control de los mejores puestos en la catedral por parte de los linajes del bando de San Benito y que nos sirven para entender cómo se tejían las lealtades entre las oligarquías salmantinas las encontramos en el AGS, en un albalá de $1465^{12}$ que señala el nombramiento como miembro del Consejo Real de la corte del rey Alfonso de Ávila a Diego Alfonso Botello, arcediano de Salamanca. Este arcediano era del linaje salmantino de los Anaya, y es un documento editado recientemente ${ }^{13}$ en el que se menciona en su texto a Juan Fernández de Hermosilla, secretario del rey Alfonso de Ávila, al arzobispo de Toledo, su Canciller Mayor en esta corte paralela, al conde de Benavente, Canciller Mayor del Sello y al maestre de Alcántara ${ }^{14}$, todos ellos de la liga de sublevados contra En-

\footnotetext{
Lор Оті́N, "Las catedrales y los cabildos catedralicios", p. 377.

$10 \quad$ Ibidem, p. 377.

11 Además de la tabla que ofrecemos en el texto, son varias las informaciones que también nos conducen a plantear que la cercanía de los de San Benito a la catedral de Salamanca era más que una proximidad de vecindad. Un texto de obligada consulta sobre la composición, las relaciones y las ocupaciones de los diferentes linajes de Salamanca es SÁnchez Vaquero, Linajes de Salamanca. Por otro lado, veremos por ejemplo cómo el oficio de deán desde 1440 y hasta 1502 está en manos de un Paz. Se cede por resignación simple a Juan Pereyra de los Anaya que a su vez se lo pasa a su hijo a lo largo del primer tercio del siglo XVI. Esto mismo lo expondremos también en el caso del beneficio patrimonial del arcedianato de Nájera, el asunto que nos ocupa en el presente trabajo y que desarrollaremos a continuación.

12 AGS, QC, leg. 2, f. 331 de julio de 1465.

13 Peláez Boismorand, Poder y movilidad social, p. 331-332 lo podemos encontrar editado.

14 En aquel año de 1466 el Maestre de la Orden de Alcántara era frey Gómez de Cáceres i Solís y toma partido por la causa del rey Alfonso de Ávila. Véase TORRES y TAPIA, Crónica de la Orden de Alcántara, p. 383. Este alineamiento del Maestre por la liga de sublevados y el rey Alfonso no es, con seguridad, institucional y se produce a título personal por frey Gómez de Cáceres.
} 
Ilustración 2

\begin{tabular}{|c|c|c|}
\hline NOMBRES, APELIDOS* & BENEFICIO OCUPADO* & APELLIDO EN BANDO: ** \\
\hline Anaya y Maldonado & Obispo & San Benito \\
\hline Rodrigo Arias Maldonado & Canónigo & San Benito \\
\hline Fernando Enríquez & Canónigo y Chantre & San Benito \\
\hline Diego de Fonseca & Canónigo & San Benito \\
\hline Juan de Fonseca & Canónigo & San Benito \\
\hline Gil García de Hontiveros & Canónigo & San Benito \\
\hline Fernando Maldonado & Canónigo & San Benito \\
\hline Alfonso Martínez de Paz & Canónigo & San Benito \\
\hline Diego Nieto & Racionero & San Benito \\
\hline Alfonso de Paz & Racionero & San Benito \\
\hline Álvaro de Paz & Deán & San Benito \\
\hline Antonio de Paz & Canónigo y Sochantre & San Benito \\
\hline Juan Pereira & Deán & San Benito \\
\hline Fernando González de Monroy & Canónigo & Santo Tomé \\
\hline
\end{tabular}

"Datos obtenidos en VICENTE BAZ, R., Los libros de las Actas Capitulares de la Catedral de Salamanca 1289-1489, Salamanca: ACS, 2008

**Aceptamos la distribución de los apellidos por bandos en Salamanca que propone LÓPEZ BENITO, C. I., Bandos Nobiliarios en Salamanca, Salamanca: Centro de Estudios Salmantinos ,1983, p. 116, que relaciona del lado de SAN BENITO a los Acevedo, Anaya, Fonseca, Godínez, Maldonado, Manzano, Paz, Pereira, Ribas, Fontíveros [Hontiveros], Nieto y Enríquez, y del lado de SANTO TOMÉ a los Almaráz, Monroy, Portocarrero, Solis, Tejeda, Valdés, Varillas y Vazquez-Coronado.

rique IV. Este documento nos ayuda a visualizar cómo eran de claras y homogéneas las adscripciones de los linajes dominantes en Salamanca en los posicionamientos políticos por el conflicto sucesorio de Enrique IV. Diego Alfonso Botello fue, como dijimos, arcediano de Salamanca y tío de Juan Pereyra que es el deán que sustituye a Álvaro de Paz cuando el puesto queda vacante por su muerte después de sesenta y dos años ocupando dicho deanato. Un año más tarde, en 1466, es el propio Álvaro de $\mathrm{Paz}^{15}$, del bando de San Benito, el a su vez es nombrado Consejero Real del rey Alfonso de Ávila. En definitiva, familias situadas en el mismo bando de San Benito, controlando las mejores posiciones de la catedral y además en el mismo lado de la balanza y con idénticos compromisos políticos en relación a las complejas divisiones del reino de Castilla.

\section{El arcedianato de Nájera, un beneficio patrimonial en Salamanca en manos del bando de San Benito}

Haremos en primer lugar una muy breve referencia al origen del topónimo "Nájera". Podemos encontrar quien refiere su relación con el vocablo anijar o nadjar, carpintero en

$\overline{15}$ AGS, EMR, QC, leg. 2, 235r de 22 abril de 1466. 
árabe ${ }^{16}$ aunque mas lejos en el tiempo aún es la propuesta realizada por el Prof. Manuel Lecuona que sugiere que el radical nahar está en la procedencia de este topónimo y de otros en La Rioja y Navarra ${ }^{17}$. Según el profesor Lecuona este radical tiene un origen semítico y significa río. En efecto el río Najerilla, atraviesa esta población riojana de Nájera. Como arcedianato en particular, en Plena y Baja Edad Media constaba de cincuenta parroquias y tenía una superficie de $781 \mathrm{Km} 2^{18}$ contando con una población de unos 4.880 vecinos a mediados del siglo $\mathrm{XVI}^{19}$. Era el territorio más densamente poblado de la diócesis y además englobaba las mejores tierras para la producción agrícola. Nájera fue sede diocesana durante la ocupación musulmana del territorio, regresando ésta a inicios del siglo XII a Calahorra. Su posición geográfica era estratégica.

Como hemos señalado en el epígrafe anterior, la división de la influencia y del poder de los dos bandos políticos salmantinos era muy equilibrada. Tanto en los territorios urbanos, como en el reparto del poder local como en el de las iglesias o parroquias, se puede hablar de un balance compensado. Sin embargo, el bando de San Benito tenía mayor influencia en la principal iglesia de la ciudad, según hemos tratado de demostrar anteriormente, y esa sola ascendencia le confería a los de este bando una cierta ventaja en el dominio social urbano. Este era un hecho no aislado en la Castilla bajomedieval ya que el manejo sobre el cuadro de dignidades de las catedrales por los bandos dominantes de las ciudades no solo se produjo en Salamanca. T. Ruiz nos refiere, por ejemplo, una similar situación en Burgos ${ }^{20}$, en donde unos grupos determinados del poder urbano monopolizaban el deanato. Clara I. López para el caso de Salamanca refiere el control que el bando de San Benito tenía también sobre el oficio de deán, el más lustroso de la catedral ${ }^{21}$. El caso de la vecina Ciudad Rodrigo resulta muy apropiado para lo que estamos comentando. Lo describen José Ignacio Martín y Rafael González en su trabajo, centrado en este caso en la villa mirobrigense. Allí el beneficio de deán, según afirman estos autores, era controlado por los Águila, un linaje importante de la oligarquía de esa ciudad, y lo hicieron a lo largo de más de cien años ${ }^{22}$.

\footnotetext{
16 رآجَنـ Era ésta una zona de extensos bosques y la explotación maderera una actividad común entre sus gentes.

17 Lecuona, Toponimia riojana, Un préstamo del..., p. 335. Explica aquí la influencia en el topónimo "Navarra" o "Nafarroa".

18 IbÁÑez Rodríguez, "La diócesis de Calahorra a mediados del siglo XVI", p. 145.

19 Ibídem, p. 156.

20 Ruzz, Sociedad y Poder Real en Castilla. Cita el caso de Burgos, en donde también se daba esta situación de control del puesto de deán y otros beneficios eclesiásticos por parte de los grupos de poder dominantes del concejo que en el caso de esta ciudad no estaban organizados en bandos como el caso salmantino.

21 López Benito, "La oligarquía salmantina en los inicios de la Edad Moderna", p. 35 donde cita textualmente: "En el ámbito eclesiástico controlaban oficios muy numerosos, e incluso el de deán que monopolizaba el bando de San Benito de manera ininterrumpida desde fines del s. XV". Véase también Peláez Boismorand, Poder y movilidad social, en donde queda bien claro este control por parte de la figura del deán Álvaro de Paz, que lo fue durante más de sesenta y dos años, además de consejero real del rey Alfonso de Ávila y de los Reyes Católicos.

22 Martín Benito, "Lucha de bandos y beneficios eclesiásticos", pp. 278-279. Asimismo, la signatura AGS, RGS, leg. 1492-07, 24 de julio de 1492 ofrece este mismo dato.
} 
Este entramado del poder local se teje con lealtades políticas, compartiendo objetivos e intereses, promoviendo una suerte de endogamia social del poder a partir de enlaces concertados y de conveniencia y en nuestro caso como veremos, también haciendo circular una moneda de intercambio para pagar o cobrar favores como fue el arcedianato de Nájera. Para analizar de modo completo las relaciones cruzadas entre los linajes salmantinos en el siglo XV, conviene incluir el asunto de este beneficio patrimonial controlado por los Anayas, los Maldonado, los Nieto, los Pereyra y los Paz, un beneficio que por diferentes fuentes manuscritas sabemos que van disfrutando unos y otros miembros de estas familias a lo largo del siglo XV, concretamente entre 1423 y 1507 , es decir, durante ochenta y cuatro años.

Falta hacer un estudio en profundidad sobre la patrimonialización de ciertos beneficios eclesiásticos, especialmente del caso de los arcedianatos. El arcediano tenía el trato en la dirección de los diáconos, en la conducta de los fieles y, lo más importante, recibía y distribuía las obligaciones y las rentas de las iglesias de su demarcación. Sus funciones eran importantes en la diócesis, sobre todo si nos fijamos en los aspectos económicos de control de las rentas de las parroquias que caían bajo su demarcación. En palabras de Santiago Ibáñez Fernández, el arcediano era las manos y los ojos del obispo tanto para lo espiritual como en lo temporal, y no era raro que fuese una plataforma para acceder a dignidades más elevadas como la de obispo ${ }^{23}$.

Es muy posible que la llegada de este beneficio a las manos de los linajes salmantinos se haya producido desde las posesiones del Patronato Regio y podría explicarse por una combinación entre el posicionamiento leal de estas familias del bando de San Benito en los conflictos que azoraron la corte castellana ante el reino de Navarra ${ }^{24} \mathrm{y}$ en especial ante el reino de Aragón a lo largo del siglo XV y por el emplazamiento territorial estratégico de dicho arcedianato. La monarquía castellana a principios del siglo XV y con el apoyo del Papa, usaría este arcedianato de Nájera para corresponder algún apoyo o para asegurar una cierta estabilidad en esa zona fronteriza con Navarra y Aragón. La diócesis de Calahorra, como afirma Díaz Bodegas, en lo político pertenecía a Castilla y en lo eclesiástico a la Provincia de Tarragona ${ }^{25}$. Más adelante en el mismo trabajo señala, sin embargo, que este control de Tarragona era alternado con el de la archidiócesis toledana.

El alcance del patronato regio sobre la Iglesia castellana a lo largo del siglo XV fue siendo cada vez más disputado por Roma. En la última sesión del concilio de Trento (XXV), días el 3 y 4 de diciembre de 1563, se abordó esta cuestión de los beneficios patrimoniales activos. La legitimidad de tales beneficios en términos de posesión venía probada si en efecto se habían gestionado la totalidad de las funciones inherentes, entre otras, la fundación de iglesias donde no las hubiese, la realización de las dotaciones

\footnotetext{
23 Rivera, La historia de Álava, p. 148.

24 Conviene recordar que el reino de Navarra fue disputado por la corona de Aragón, la de Castilla y por el reino de Francia. A mediados del siglo XV se desarrolla la larga guerra civil entre beamonteses, con el apoyo de Castilla, y la facción nobiliaria de los agramonteses apoyados por la corona de Aragón y luego por la de Francia.

25 Diaz Bodegas, "La diócesis de Calahorra en la Edad Media", p. 460.
} 
necesarias a las mismas, la presentación de ministros para dichas iglesias ${ }^{26}$, es decir, lógicamente más allá de la mera, interesada y lucrativa gestión financiera de la demarcación eclesiástica.

Aún siendo una información de fuente tardía, el interés que como beneficio eclesiástico despertaba un arcedianato podríamos entenderlo mejor si nos fijamos en el contenido de lo firmado en el Concordato de 1753 entre la monarquía española y la Santa Sede. Este Concordato zanjaba además las diferencias que quedaron sin resolver tras la consecución por la corona española del Patronato Universal sobre su Iglesia en 1523 con Adriano VI. Pues bien, uno de los acuerdos se refiere a cincuenta y dos beneficios eclesiásticos de la Iglesia española que quedaron bajo el dominio absoluto de Roma tras su firma. La apetencia de Roma se dirigía con preferencia hacia los arcedianatos tal como vemos en el gráfico a continuación. La ascendencia en materia de conductas de la feligresía y el control sobre los frutos económicos, por sí solos eran suficientes motivos.

En la diócesis de Salamanca es el arcedianato de Monleón el que, tras dicho acuerdo, quedó bajo custodia del Papa $^{27}$ :

\section{Ilustración 3}

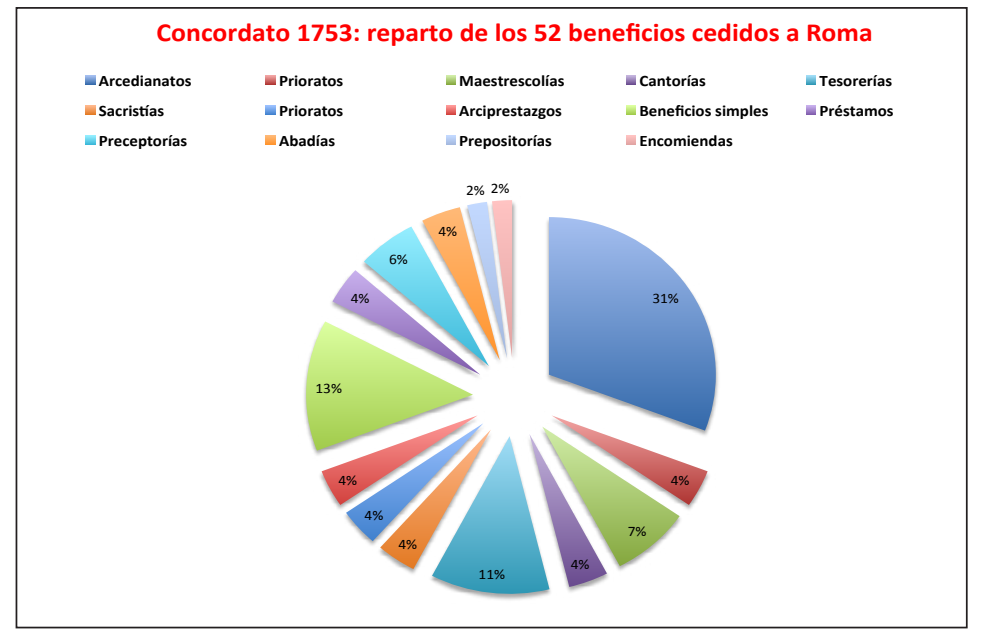

26 Llorente, Discursos Histórico-Canónicos, p. 48.

27 Tal vez pueda ser ilustrativo de la importancia del arcedianato como beneficio eclesiástico el siguiente dato: El Concordato que se firma el 18 de octubre de 1753 entre Benedicto XIV y el rey Fernando VI, consigue zanjar algunas controversias que aún persistían sobre el Real Patronato Universal de los reyes españoles sobre su Iglesia. En este Concordato se resuelve que: ...reserva [el Papa] á su privativa libre Colación, á sus sucesores [Papas], y á la Sede Apostólica perpetuamente çinquenta y dos Beneficios cuyos títulos... De esos títulos que se relacionan a continuación, dieciséis son arcedianatos, es decir un 33\%. Uno de ellos el de Nájera. El resto se lo reparten hasta doce tipos de beneficios diferentes. El dato lo podemos consultar en: Tomo primero de las Leyes de Recopilación que contiene los Libros Primero, segundo, tercero, quarto i quinto, ed. Imprenta Pedro Marín, Madrid MDCCLXXII (1772), p. 46 (Libro $1^{\circ}$ de la Santa Fe Cathólica). 
Pero vamos a tratar de recorrer con la ayuda de la documentación manuscrita editada y no editada, el rastro que ha quedado de este arcedianato de Nájera como bien patrimonial de uso privativo para ciertos apellidos salmantinos como los Anaya, los Maldonado, los Nieto, los Pereyra y los Paz. Estas familias contaron con canónigos, arcedianos de Salamanca, deanes y otras dignidades durante este siglo XV e inicios del siglo XVI y eran unos linajes que estaban más vinculados al bando de San Benito. En este recorrido tendremos finalmente ocasión de comprobar, cuando surge la vacante del deanato de la catedral de Salamanca en 1502, el papel que juega este beneficio al servicio del juego de intereses cruzados entre estos linajes salmantinos para continuar con el dominio de este apetecido puesto de la catedral.

El arcedianato de Nájera, visto territorialmente, dependía de la diócesis de Calahorra, una diócesis que unida a la de Burgos y a la de Palencia en la Edad Media formaban los tres ejemplos mejor documentados de iglesias patrimoniales. Esta condición queda así claramente reflejada en el tomo primero de las Leyes de Recopilación:

...Mandamos que las Bulas, i Privilegios Apostólicos, que a nuestra suplicación, i de los Reyes nuestros progenitores han sido concedidas por los Summos Pontifices passados, en que confirmaron, $i$ aprobaron la costumbre antiquíssima, $i$ orden, que se ha tenido, $i$ guardado en los Obispados de Burgos, i Palencia, i Calahorra cerca de la provisión de Beneficios a hijos (a) patrimoniales, se guarden, i cumplan en todo, i por todo... ${ }^{28}$

Empezaremos ahora con un gran salto atrás en el tiempo para irnos al año 1085, durante el transcurso de las primeras actuaciones de repoblamiento acometidas por Raimundo de Borgoña en esta zona. Sabemos que la población de Cíperez [Cípedrez], al oeste de Salamanca, es repoblada por riojanos. El fundador de esta localidad es, según datos de su historia local, Ziti Petriz, merino de Nájera ${ }^{29}$. Cuatrocientos años después, al final del siglo XV, Cíperez era una parroquia que caía bajo la jurisdicción de la catedral de Salamanca y es más, el beneficiado directo en lo económico y jurisdiccional era el deán de la catedral, Álvaro de $\mathrm{Paz}^{30}$, perteneciente al bando de San Benito. Como decimos son datos que por sí mismos no nos explican en absoluto la llegada de este beneficio eclesiástico al control de las mencionadas familias salmantinas, pero que indudablemente tienden causal o casualmente un puente entre esta población riojana con la provincia

\footnotetext{
28 Tomo primero de las Leyes de Recopilación que..., p. 20 (Libro $1^{\circ}$ de la Santa Fe Cathólica). Se pide la confirmación de una Pragmática emitida en Valladolid en 1523.

${ }_{29}$ Barrios García, "Repoblación de la zona meridional del Duero", p. 81 y nota a pie $\mathrm{n}^{\mathrm{o}} 158$. Otra información sobre esta circunstancia la podemos leer así como consultar en el enlace https:// cronologiahistorica.com/tag/ciperez/ (08/02/2018) en donde se afirma que Ziti Petriz sería arcediano de Nájera aunque no se contrasta esta información con ninguna fuente.

30 ACS, Cajón 70, AC 21, f. 41v.
} 
de Salamanca. Ángel Barrios refiere que el tal merino de Nájera aparece también como firmante en una escritura de dotación de la catedral de Salamanca en el año $1085^{31}$.

Una explicación a este hecho constatado podría residir en el carácter patrimonial de la Iglesia de Calahorra (entiéndase diócesis) y que ya antes hemos comentado. Una circunstancia que viene de antiguo según la fuente $\operatorname{citada}^{32}$ y que para acabar en las manos de linajes salmantinos debería de haber tenido un patrono que abarcara todo el reino de Castilla, de manera que esto sólo se explicaría si este arcedianato formase parte directa del Patronato Regio. Lo que parece probado es que en la diócesis de Calahorra, en concreto y sobre las instituciones siguientes, el monasterio de Santa María la Real, la Capilla Real de la Cruz y el Hospital del Emperador, todos ellos beneficios situados en Nájera existían derechos de Patronato Real ${ }^{33}$.

La documentación más temprana sobre este asunto la recoge Beltrán de Heredia en su Bulario y es de finales del siglo XIV. Ya en ese momento vemos como este beneficio es cedido por el Papa Clemente VII a Roberto de Moya ${ }^{34}$. En 1423 el arcedianato de Nájera llega por fin a Salamanca al caer bajo el control de Diego Alfonso de Botello, sobrino del cardenal Pedro de Fonseca (cardenal de SantAngelo) y canónigo de la catedral de Salamanca. El cedente de estos frutos es el mencionado Roberto de Moya ${ }^{35}$.

El cardenal Pedro de Fonseca, aunque bien relacionado con el Papa Luna Benedicto XIII, es uno de los tres cardenales españoles que se posicionan al lado de Martín V después de 1418. Goza este cardenal, por lo tanto, del favor de la curia romana gracias a lo cual intercede con frecuencia en favor de sus intereses logrando diferentes nombramientos a allegados y a propios. El cedente, Roberto de Moya, había mediado en 1412 en un largo conflicto entre el monasterio de Santa María la Real de Nájera y el obispado de Calahorra con don Diego de Zúñiga, su obispo al frente. Este monasterio reclamaba su condición como sede obispal desde hacía mas de dos siglos y se mostraba remiso a someterse al control de la diócesis calagurritana. No es el objetivo de este trabajo ahondar en esta cuestión; solo interesa apuntar, eso sí, que la intermediación de Roberto de Moya, deán de Córdoba y arcediano de Nájera que era tenido como...

\footnotetext{
31 Barrios García, "Repoblación de la zona meridional del Duero", nota a pie 159.

32 Tomo primero de las Leyes de Recopilación que..., p. 20.

33 IbÁÑez Rodríguez, "La diócesis de Calahorra a mediados del siglo XVI", p. 164. También vemos el dato en AHN, Códices, L. 776, ff. 169 y 170.

34 Beltrán de Heredia, Bulario de la Universidad de Salamanca 1218-1549, (vol. II), p. 249 y refiere una signatura del Registro Aviñonense: ASV, Reg. Avin. 242, ff. 490 y 496 del año 1395. El mismo volumen en su p. 181 alude al traspaso del Arcedianato a Diego Alfonso Botello: ASV, Reg. Lat. 228, ff. 107-108 y es del año 1423.

35 Beltrán de Heredia, Bulario de la Universidad de Salamanca (vol. I), p. 181. Cita las siguientes signaturas: ASV, Reg. Lat. 228, f. 107-108 y f. 157v-159r que recoge la llegada a manos de Diego Alfonso de Botello del arcedianato de Nájera y ASV, Reg. Suppl. 390, f. 83 en el que vemos que se le permite retener el arcedianato de Nájera junto al de Salamanca hasta 1462. Roberto de Moya es promovido a la Abadía de Valladolid (germen de la futura diócesis).
} 
insigne varón de aquellos siglos por sus letras y conocidas prendas... ${ }^{36}$, es quien en 1412, obtenida la oportuna jurisdicción, dicta una sentencia que es recogida en una bula papal y que determina los ámbitos competenciales exclusivos de la diócesis de Calahorra y del monasterio de Santa María la Real. Este laudo viene a reconocer en cierto modo las reivindicaciones de los abades del monasterio que querían recibir el trato que les correspondía como antigua sede episcopal. El arcedianato de Nájera quedaba en 1412 liberado de la ascendencia de la diócesis calagurritana y no volverían los conflictos hasta después del largo concilio de Trento, por la aplicación de algunas de sus resoluciones.

Sobre Diego Alfonso Botello, sobrino del cardenal Pedro de Fonseca, podemos decir que ya en 1436 era canónigo de la catedral de Salamanca y desde 1443 arcediano de Salamanca. Tenemos, sin embargo, el primer registro en las actas capitulares como arcediano de Salamanca el 7 de marzo de $1466^{37}$.

Inmediatamente en el tiempo tenemos informaciones en las actas capitulares de la catedral de Salamanca de un racionero, Diego Nieto, que entre 1467 y 1485 es tenido como arcediano de Nájera también ${ }^{38}$.

A partir de 1487 constatamos que el arcedianato lo disfruta un sobrino de Diego de Botello, Juan Pereyra ${ }^{39}$, el que sería deán de la catedral después de Álvaro de Paz y del linaje de los Anaya, afín al bando salamantino de San Benito al igual que los Paz. Juan Pereyra disfruta del arcedianato de Nájera, al menos, desde 1487, según comprobamos en el texto siguiente:

...Don Fernando e dona Isabel, a vos Juan Pereyra harcediano de Nájera, salud e gracia, sepades que nos somos... ${ }^{40}$.

Encontramos asimismo evidencias documentales de la posición de Juan Pereyra como arcediano de Nájera ${ }^{41}$ en las actas capitulares del ACS. En esta acta, vemos que se refiere a una venta del ...lugar de Morille... perteneciente al arcediano Juan Pereyra que es tratado como arcediano de Nájera: ...dicho lugar que compraron de su arcediano de Nájara ... ${ }^{42}$.

36 Náxara Ilustrada, ed. Patronato del Monasterio de Santa María la Real de Nájera, fray Juan de Salazar, 1987, p. 122.

37 ACS, Cajón 70, AC 3, f. 3r.

38 ACS, Cajón 70, AC 7, f. 24 de 1482.

39 ACS, Cajón 70, AC 13, f. 3v de 10 de julio de 1489 se ofrece la información sobre la relación familiar entre Diego de Botello y Juan Pereyra.

40 AGS, RGS, leg. 1487-12, f. 157.

41 En algún momento Juan Pereyra decide arrendar los frutos del arcedianato a un ciudadano de Santo Domingo [de la Calzada] tal como veremos en el epígrafe 3.

42 ACS, Cajón 70, AC 12, f. 49v. Véase Los libros de las actas capitulares de la catedral de Salamanca (1298-1489). 
En 1498 hallamos el arcedianato en manos de Diego Rodríguez de Santisidro, canónigo de la catedral de Salamanca. Este canónigo es hijo de Juan Arias Maldonado, señor del Maderal ${ }^{43}$ de los Maldonado y que era a su vez yerno del Dr. Talavera. Vemos ya rastro de los Anaya, los Paz, los Nieto, los Pereyra y los Maldonado apellidos del bando de San Benito de Salamanca en estas signaturas documentales. En el texto siguiente verificamos esta última información:

...Don Fernando e dona Isabel, a vos don Diego Rodrigues de Santysidro, arcediano de Nájera e canónigo de la iglesia de Salamanca e Sigüenza... ${ }^{44}$.

Concluyendo el desarrollo, en 1502 comprobamos que es Antonio de Paz, hijo de Álvaro de Paz, quien es tratado como arcediano de Nájera:

...segund es de huso e de costumbre y el señor don Antonio de Paz arcediano de Nájera, canónigo de dicha iglesia que presente estaba... ${ }^{45}$.

Antonio de Paz, hijo de Álvaro de Paz, se beneficia de este arcedianato hasta 1507, año en que pasa por fin a manos de Francisco de Fuentes ${ }^{46}$.

Es decir, y recapitulando, es un beneficio eclesiástico patrimonializado y cuya posesión pasa de mano en mano entre canónigos y dignidades de la catedral de Salamanca. Esto parece irrefutable a tenor de la persistente información que ofrecen las fuentes. Una conjetura a proponer sería que pueda ser una suerte de moneda de cambio en el juego de intereses cruzados entre familias de la oligarquía y del patriciado urbano de Salamanca. Desde luego tal parece si lo planteamos desde el siguiente punto de vista: Álvaro de Paz accede a una canonjía en 1440 gracias a una vacante generada por Joannis Gomecii (Juan Gómez de Anaya) y como consecuencia de una Letra Apostólica de Expectativa ${ }^{47}$. Hasta el fallecimiento del deán, sucedido en 1502, el arcedianato de Nájera va pasando sucesivamente de Diego Botello (Anaya) a Diego Nieto, después pasa a Diego Rodríguez de Santisidro (Maldonado, por ser hijo de Juan Arias Maldonado, señor del Maderal ${ }^{48}$ ), cayendo por último este beneficio en manos de los Paz en la figura de Antonio de Paz. A este Paz, hijo del deán, le llega de manos de Juan Pereyra. En ese momento Álvaro de Paz, por resignación simple, designa precisamente a Juan Pereyra como su sucesor y causalmente o casualmente, no sabemos, el arcedianato de Nájera se transfiere de Juan

\footnotetext{
43 Villar y Macías, Historia de Salamanca, libro V, “desde el corregimiento..., p. 107.

44 AGS, RGS, leg. 1498-05, f. 345.

45 ACS, Cajón 70, AC 21, f. 31v.

46 Documentación calagurritana del siglo $X V$, p. 563.

47 ASV, Reg. Suppl. 367, f. 85v de fecha 10 de septiembre de 1440.

48 Juan Arias Maldonado casó en segundas nupcias con la hija menor del Dr. Talavera. Para más detalles sobre las relaciones políticas y familiares del Dr. Talavera véase SANTOS BuRGALETA, "Extensiones de poder: Una propuesta de análisis"
} 
Pereyra a Antonio de Paz. Lo que resulta una evidencia es el acceso a un canonicato por los Paz (Álvaro) a partir de una vacante generada por un Anaya y que sesenta y dos años después, Álvaro de Paz entregue el deanato salmantino a un Anaya, Juan Pereyra. Visto en conjunto, parece un circuito de favores que se cierra en $1507^{49}$.

Para dar consistencia a esta teoría de instrumento que, a nuestro juicio, tenía el arcedianato de Nájera, la documentación analizada procedente del AGS sobre la provisión de esta vacante menciona de forma explícita que Juan Pereyra logra el deanato merced a unas permutaciones. Esto nos permite mantener esta hipótesis del carácter de moneda de cambio que tuvo el dicho beneficio al servicio de la oligarquía salmantina dominadora de los beneficios eclesiásticos de su catedral:

...Ruego vos mucho quel/tengáys manera con las permutaçiones que se fisieren a fin de dar este deanadgol/a Juan Pereyra se desfagan, de manera que él se torne a su arçidianadgo de//Salamanca... ${ }^{50}$

Todos los componentes de los linajes salmantinos que se beneficiaron del patronato sobre el arcedianato de Nájera eran a su vez canónigos de la catedral de Salamanca. No era infrecuente en este contexto que un clérigo disfrutase de los frutos de más de un beneficio. Así podemos citar, como ejemplo, el caso de don Fernando Alonso, hijo de Alfonso X que, al mismo tiempo, era deán de Santiago y arcediano de Salamanca, el de Alfonso Vidal, arcediano de Alba de Tormes y deán de Ávila ${ }^{51}$ o, por citar otro ejemplo entre muchos que hay, el caso de un personaje importante durante la primera mitad del reinado de Enrique IV, Rodrigo Sánchez de Arévalo que en 1456 es promovido al deanato de Sevilla conservando los beneficios que ya disfrutaba de deán de León, arcediano de Burgos y arcediano de Treviño ${ }^{52}$. El propio Álvaro de Paz y, según se desprende de las fuentes vaticanas especialmente, llegó a disfrutar de diferentes beneficios en la iglesia toledana, la abulense y en la salmantina simultáneamente.

Este disfrute de varios beneficios por un solo clérigo ha sido estudiado y recogido en su tesis doctoral, para el caso de los presbíteros que son rectores y vicarios de doce parroquias de la ciudad de Valencia, por $\mathrm{M}^{\mathrm{a}}$ Nieves Munsuri. En este sentido esta autora ofrece en su tesis una serie de datos que hemos resumido en el anexo 4 y que están relacionados con el disfrute individual de múltiples beneficios ${ }^{53}$. La acumulación de beneficios forma parte también de la normalidad en este retrato social que tratamos de hacer así como del entorno económico-laboral del clero, en palabras de la Dra. Munsuri. A los presbíteros les estaba prohibida otra actividad profesional que la propia gestión del beneficio acentuándose así las fronteras con la sociedad civil: cada uno con su actividad

\footnotetext{
Se ofrece un esquema en los anexos documentales.

ACS, CCa, Ced 6, 2-1, no 1 .

Martín Martín, El cabildo de la catedral de Salamanca, p. 34.

NIETO SORIA, "Enrique IV de Castilla", p. 192 en nota a pie n ${ }^{\circ} 96$.

Munsuri Rosado, Perspectiva socio-económica, p. 464. Ver anexo a continuación.
} 
económica y régimen fiscal y cada uno en su ámbito judicial. Señala también en su tesis doctoral como aquellos que inician su carrera eclesiástica, los clérigos menores, acumulan menos beneficios que aquellos que ya son presbíteros y que llevan ya unos años de andadura. El beneficio era fundamentalmente un patrimonio, un recurso con el que sustentarse, pero también una protección frente a la justicia secular puesto que los clérigos sólo estaban sometidos a la justicia episcopal.

En esta misma línea argumental, la profesora Silvia María Pérez González nos relata también cómo algunos clérigos acumularon hasta siete rentas eclesiásticas según un estudio presentado por ella. En este trabajo advierte sin embargo que la normativa canónica obligaba a que cada beneficio creado tuviese la oportuna y suficiente dotación económica ${ }^{54}$, y que como esto no siempre sucedía ello obligaba a los clérigos a buscar otras fuentes de ingresos apoyándose generalmente en más beneficios eclesiásticos. Cita esta autora el Concilio Nacional de Valladolid del año 1322 que en sus cánones 9 y 10 aludía a este citado requerimiento económico. Este importante sínodo castellano veló además para que las parroquias de la diócesis con una determinada extensión y calidad tuviesen maestros en gramática y en lógica así como que hubiera clérigos formados en las escuelas catedralicias. Las iglesias debían poner al servicio de los feligreses también unas tablas con los contenidos doctrinales mínimos y con los mandamientos divinos, pese a que posiblemente la mayoría de los cuales feligreses fuesen analfabetos y fueran las imágenes las que fundamentalmente ayudaran a integrar el relato bíblico.

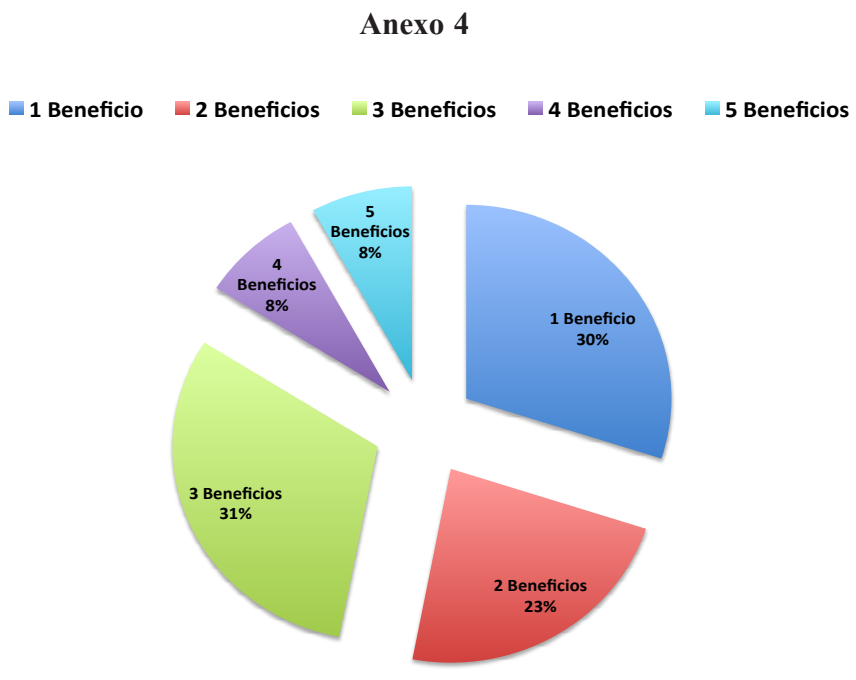

54 Pérez González, "Los beneficios parroquiales: un acercamiento", pp. 516-518, cita a pie no 81. 
Como vemos en este anexo las estadísticas del trabajo de Nieves Munsuri son claras: un $70 \%$ de los clérigos de dicho estudio poseen y disfrutan de más de un beneficio eclesiástico lo que confirma que esta situación en relativamente frecuente.

\section{La patrimonialización llevada al límite: su arrendamiento a un tercero}

Haremos una referencia separada a un documento de la cancillería castellana, del Registro General del Sello, fechado en 1500 (Sevilla) y cuya signatura es AGS, RGS, 1500-04, f. 109. En él, en síntesis, se solicita al maestreescuela del Estudio Salmantino que se inhiba e incluso se retracte, si fuera necesario, de cualquier acción judicial en favor del estudiante Juan Pereyra, hijo del canónigo llamado Juan Pereyra también. Este personaje ostentó los cargos de arcediano de Salamanca y posteriormente deán de la catedral de Salamanca ${ }^{55}$. Como miembro de una familia del bando de San Benito, también tuvo ocasión de poseer y disfrutar los frutos del arcedianato de Nájera como hemos visto. El principal argumento jurídico expuesto en el documento es la distancia entre Santo Domingo y el obispado de Salamanca:

...dis que la dicha çibdad de Santo Domingo,//donde el dicho Diego Fernandes de Mixanas bibe,//dista e está apartado de los confines del obispado //de Salamanca, a más y allende//de las dos dietas ${ }^{56}$, dentro...

El pleito entre Juan Pereyra padre (canónigo de la catedral de Salamanca) y más adelante Juan Pereyra hijo (estudiante) con el ciudadano de Santo Domingo [De la Calzada] Diego Fernandes Mixanas, tiene en su base el arcedianato de Nájera. Lo que se relata en él es que este ciudadano de Santo Domingo, que había arrendado por ciertos años los frutos del arcedianato de Nájera, no habría podido responder con el pago de las tercias reales al fisco regio, dado que la salida del reino de los judíos habría provocado una merma importante en la percepción de los diezmos ligados al arcedianato de Nájera:

...disiendo que//él ovo arrendado çiertos años los frutos e//rentas del Arçedianadgo de Nájera del arçe-//diano Juan Pereyra, arçediano que fue de Nájera,//e dis que como al dicho tiempo salieron los judios// destos nuestros reynos, el diesmo de los quales dis//que pertenesçía al dicho Arçedianadgo,

\footnotetext{
55 Véase Peláez Boismorand, Poder y movilidad social...Abundan las referencias a este personaje, especialmente en el epígrafe 3.3.3.3. que aborda la cuestión de la transición del deanato de la catedral de Salamanca.

56 Ya comentamos en la nota a pie 2 que la distancia entre Salamanca y Santo Domingo [De la Calzada] o Nájera suponía al menos dos días de viaje. El texto original refiere explícitamente "allende de las dos dietas". Conviene aclarar que en el seno del Concilio Lateranense IV, canon 37, celebrado en tiempos de Inocencio III (1215-16) se dispuso ahí que las partes en litigio no podían llevar su causa judicial más allá de dos dietas de distancia de sus respectivas diócesis.
} 
en la vega [?]//de Grañón e otros logares, e dis que porque no le // acudieron con los frutos e rentas de los dichos// terçios los dezmeros e reçebtores dello, él//no pudo pagar lo que asý montauan los dichos//terçios...

Este manuscrito nos dirige hacia varias informaciones. La primera, la más evidente, nos permite ver claramente el carácter de bien mercantilizado que alcanzó la tenencia de este arcedianato. Nada sobre la gestión del solar espiritual de las diferentes feligresías, nada sobre erección de nuevas iglesias, nada sobre la presentación de nuevos ministros al obispo. Se arrienda por unos años a un vecino, no a un clérigo, de tal manera que tenemos a este ciudadano, pechero o exento, no sabemos, como el primer receptor de los frutos de un arcedianazgo importante.

Otro elemento a tener en consideración es que la responsabilidad de responder ante el fisco regio con las tercias correspondientes a los diezmos recaudados en cada una de las cincuenta parroquias con que contaba el arcedianato de Nájera, parece corresponder al tenedor principal del arcedianato, es decir, a Juan Pereyra. Éste, al no recibir las rentas acordadas por el arriendo del arcedianato, inicia el proceso judicial contra el ciudadano Diego Fernandes Mixanas al que...por fatigarle... continúa hostigándole judicialmente al traspasar el proceso a su hijo de igual nombre.

En definitiva, asistimos al arrendamiento de un beneficio eclesiástico como si de una propiedad rústica o urbana se tratase y realizada a un ciudadano aparentemente no vinculado al clero. Según Silvia María Pérez ${ }^{57}$, este arrendamiento sobre los frutos pasa por que el cedente otorgue un poder al arrendador, asegurándose una cantidad fija y liberándose de recaudarlos y cobrarlos. Esto no hacía necesario al propietario del beneficio arrendado de residir en este territorio, como de hecho ocurre en esta situación. Esta práctica era también común para el caso de ciertos impuestos concejiles que se arrendaban al mejor postor en pública almoneda. Con este documento queda recogido el caso del arrendamiento a un tercero de rentas eclesiásticas producidas por un beneficio patrimonializado.

\section{Conclusiones}

El beneficio, tal como aparece probado, pasa por las manos de canónigos del bando de San Benito de la ciudad de Salamanca entre el año 1423, año en que lo recibe un miembro de la familia Anaya, y hasta el año 1507 en que un tal Francisco Fuentes lo recibe procedente de un miembro de la familia Paz quedando aparentemente ya fuera del control del bando de San Benito.

57 Pérez GonzÁlez, "Los beneficios parroquiales: un acercamiento", p. 504. 
En algún momento en el entorno de los años ochenta del siglo XV, el disfrute del arcedianato es arrendado a un ciudadano de Santo Domingo [de la Calzada] lo cual genera un pleito entre dicho ciudadano, Diego Fernández Mixanas y la familia Pereyra (Anaya) de Salamanca, como ha quedado explicado.

Hasta aquí nada que no se supiese ya. La posesión en manos privadas, con el concurso del Patronato Regio, de ciertos beneficios eclesiásticos formaba parte del paisaje social de ese momento. Ya sean los nombramientos, ya las presentaciones, disputadas a Roma y a las propias diócesis, ya el mismo aprovechamiento de los frutos que estos beneficios generaban en forma de diezmos o donaciones, muchas veces ocurría fuera del control de la jerarquía eclesiástica y ello no cesó hasta bien entrada la Edad Moderna.

En este caso, dado el carácter netamente político y de búsqueda de preeminencia y poder social que catalizaba la unión de las familias del bando de San Benito, el arcedianato de Nájera fue simplemente un instrumento más, una moneda de cambio a ese servicio: alcanzar, preservar y reproducir el poder y la movilidad social.

El arrendamiento del beneficio a un tercero ahonda aún más en su carácter de bien privativo capitalizado aparentemente sin otras consideraciones ligadas al espacio espiritual tal como debería tener. El arcedianato interesa porque produce dinero, se subasta al mejor postor y se le derivan al arrendador las obligaciones recaudatorias.

Pero aún cabría una conclusión más desde una visión externa a la de los linajes salmantinos. Ya mencionamos la influencia política que tenía Castilla en la diócesis de Calahorra. Dentro de esta diócesis, Nájera es un territorio que a sus costados tiene los límites del reino de Castilla, el de Navarra y el de Aragón. Desde inicios del siglo XIII (1231), la corte castellana favoreció el fortalecimiento de la diócesis calagurritana para asegurar esta influencia. Poner en manos del bando de San Benito el arcedianato de Nájera, uno de los más importantes, más ricos y más densamente poblados de la diócesis sería una hábil y lógica maniobra. Al margen de las causalidades mencionadas en este texto y que ponen en relación el repoblamiento por riojanos de los territorios adyacentes al Duero tras la reconquista de esta zona en el siglo XI, nos inclinamos a pensar que la llegada del arcedianato de Nájera a manos de los linajes salmantinos se hace desde el Patronato Regio a donde llegaría por esta mencionada ascendencia castellana en el territorio. Estas familias venían mostrando una inequívoca lealtad a los intereses de Castilla a lo largo del siglo XV. Cabría un clásico análisis complementario en el marco de las relaciones sociales de carácter feudovasallático: el Rey cede un patrimonio territorial [eclesiástico] que produce pingües beneficios ${ }^{58}$ a cambio de que éste sea cuidado y protegido por unos vasallos, las familias del bando de San Benito que a lo largo del siglo XV se mostraron probadamente leales.

\footnotetext{
58 CATALÁn MARTínez, "Derecho de patronato y el régimen beneficial de la Iglesia española". En la p. 138 se recuerda que el patronazgo otorgaba el derecho a la recepción de las donaciones y de las limosnas que pródigamente ofrecían los feligreses para la salvación de su alma debido en el marco de la formulación socialmente aceptada sobre la existencia del purgatorio. También la recaudación de los diezmos era otra atribución en la gestión del beneficio patrimonial eclesiástico.
} 


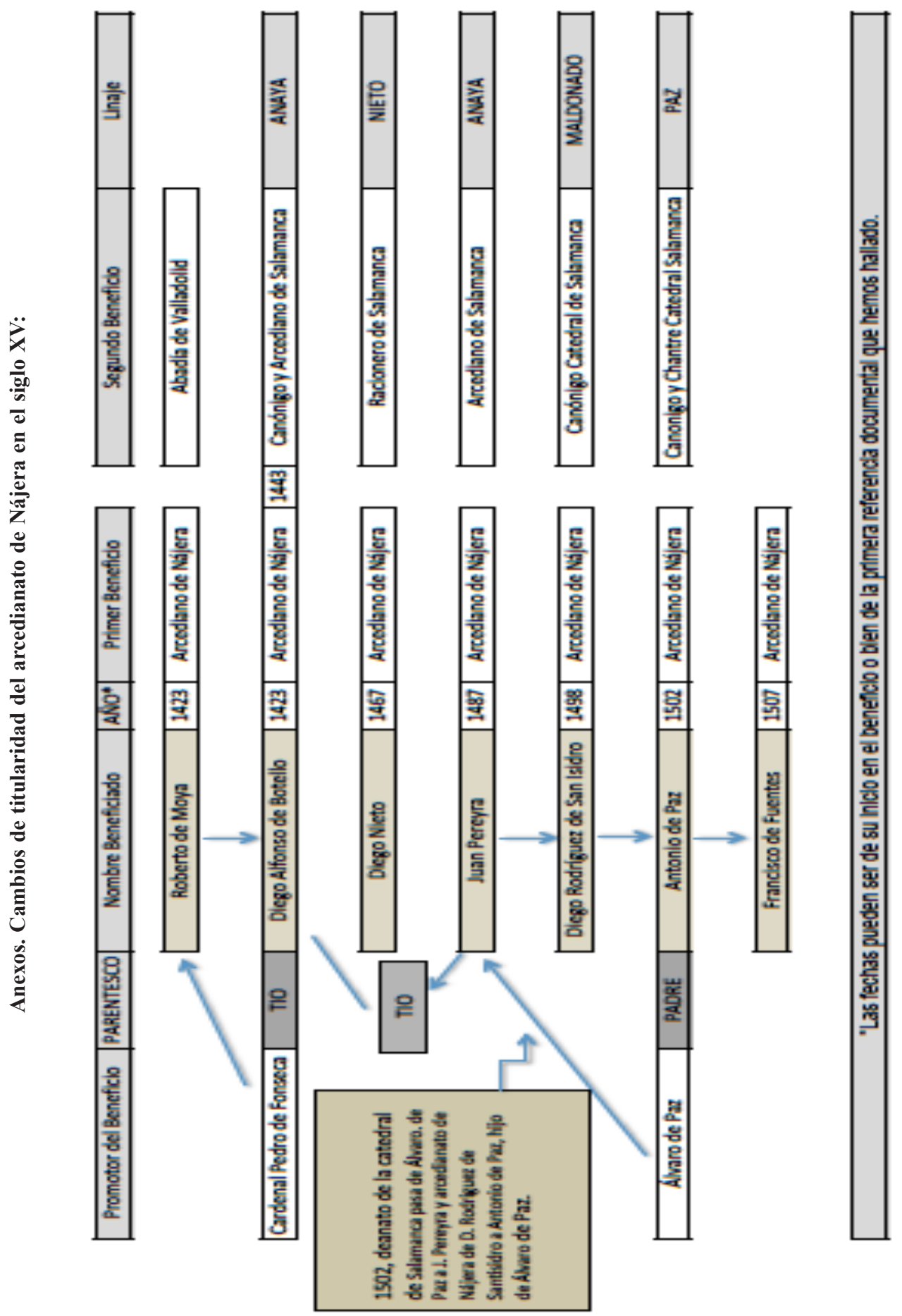




\title{
Fuentes primarias: signaturas y transcripciones.
}

\author{
1440, septiembre 10. Florencia.
}

Se confirma la aceptación de un canonicato obtenido por el deán Álvaro de Paz en Salamanca en virtud de expectativa.

ASV, Reg. Suppl. 367, f. 85v. Editado: Beltrán de Heredia, Vicente, Bulario de la Universidad de Salamanca 1218-1549, 1966, doc. 981, (t. II).

...Beatissime pater: Alias vacantibus quibusdam canonicatu et praebenda eccl. Salamantin. ac. nonnullis praestimoniis, praestimon. portionibus ac simplicibus benef. in civ. et dio. Hispalem et Salamantin. existentibus per obitum quondam Joannis Gomecii de Anaya, ultimi possesoris eorumdem, estra Rom. cur. defuncti, Alvarus de Pace, Decanus dictae eccl. Salamantin., illus et illa ejusdem gratiae suae expectativae ac nonnullarum extensionum desuper vigore infra tempus debitum et alias legitime acceptavit et de eisdem sibi vigore processus inde super factis obtinuit provideri, ac nonnullorum ex illis possessionem extitit assecutus prout possidet de praesenti. Verum, clemetissime pater, quia aliquibus de causis idem Alvarus dubitat acceptationem et possesionem de canon. et praeb., praestim. et praest. positionibus praedictis factas viribus non subsistere, supplicat s.v. quat. acceptationem et provisionem omniaque et singula ex eisdem secuta ex certa vestra scientia rata habentes et grata, supplensque ex simili vestra scientia omnes et singulos defectus, si qui forsan in eis intervenerunt, necnon praefato Alvaro de dictis can. et praeb., praestim., praest. port. et simpl. beneficiis, quorum ómnium fructus mille et centum libras val. annuum non excedunt, providere de novo de gratia speciali, decanatu dictae eccl. Salamantin. et Abulen., ac quibusdam aliis can. quos possidet et super quibus in palatio apost. litigat, quorum trecentarum librarum Tur. val. annuum non excedunt, ceterisque in contrarium facientibus non obstan. Concessum ut petitur, in praes. dom. n. Papae C. Ariminen. Datum Florentiae quarto idus septembris anno decimo...

\section{Traducción:}

...Beatísimo padre: Álvaro de Paz, deán de dicha iglesia salmantina aceptó otras entre las diferentes vacantes, un canonicato y una prebenda en la iglesia salmantina y algunos prestimonios y partes de prestimonios y sencillos beneficios en la ciudad y diócesis Hispalense y Salmantina, existentes a causa de la muerte de un tal Juan Gómez de Anaya, último propietario de éstos, muerto en la Curia Romana. Aquel aceptó unas y otras legalmente, en virtud de expectativa. Y en menos tiempo del debido consiguió alcanzar la posesión de algunos de aquellos que sigue poseyendo en la actualidad. En verdad, clementísimo padre, puesto que por algunas causas el mismo Álvaro duda de que la aceptación...//...Álvaro no habría sido nombrado al frente de dichos canonicato y prebendas, prestimonios, partes de prestimonios y simples beneficios cuyo valor no va más allá de cien libras de renta al año que vele de nuevo, como un favor especial, por el deanato de la dicha iglesia Salmantina y...//prestimonios y partes de prestimonios y 
sencillos beneficios en la ciudad y diócesis Hispalense y Salmantina, existentes a causa de la muerte de un tal Juan Gómez de Anaya, último propietario de éstos, muerto en la Curia Romana. Aquel aceptó unas y otras legalmente, en virtud de expectativa. Y en menos tiempo del debido consiguió alcanzar la posesión de algunos de aquellos que sigue poseyendo en la actualidad. En verdad, clementísimo padre, puesto que por algunas causas el mismo Álvaro duda de que la aceptación y posesión del canonicato, prebendas, prestimonios y partes de prestimonios realizadas no subsistan en las circunstancias dichas de antemano, suplica s.v. quat. la aceptación y previsión y todas y cada una de las cosas que se originen de los mismos desde vuestra razonable sabiduría. Y reparando todas y cada una de las debilidades desde vuestro razonamiento, si alguna vez intervinieron en éstas, Álvaro no habría sido nombrado al frente de dichos canonicato y prebendas, prestimonios, partes de prestimonios y simples beneficios cuyo valor no va más allá de cien libras de renta al año que vele de nuevo, como un favor especial, por el decanato de la dicha iglesia Salmantina y Abulense y de otros canonicatos que posee y sobre los cuales está pleiteando en el Palacio apostólico cuyo valor no pasa de las trescientas libras Turcas? de renta anual y los restantes que no llegan a eso. Concedido lo que se pide, en presencia del señor nuestro Papa C Ariminen.

Fechado en Florencia cuarto idus de septiembre año décimo...

1465, julio, 28. Salamanca.

Albalá de merced nombrando al arcediano de Salamanca, Diego Botello del linaje de los Anaya, miembro del Consejo Real del rey niño Alfonso de Ávila, y con una quitación de $30.000 \mathrm{mrs}$.

\section{AGS, EMR, QC, leg. 2, f. 331.}

...Salamanca//...//...//Al arcediano don Diego Botello del [con: tachado]//.../...//Consejo del Rey nuestro señor $/ / \ldots / / \ldots / /$ mostró una alvalá del Rey nuestro señor//...//.../firmada de su nombre fecho en esta guisa//e yo el rey fago saber a vos los mys contadores mayores//que my merced e voluntad es de tomar por del my Consejo a don Diego// botello, arçediano dela yglesia de Salamanca et que aya e tenga de my//de quitación en cada un anno de aquí en adelante conel dicho ofiçio treynta//myll mrs. por que vos mando quelo pongades e asentedes asý//en los mys libros e nomynas de las quitaçiones et libredes al dicho//arcediano los dychos treynta myll mrs. este anno de la fecha//desde my albalá e dende en adelante en cada un anno segund//e quando librarades a los otros del my Consejo e ofiçiales dela //...//.../[en margen derecho: XXX U]//my casa los semejantes mrs. que de my tiennen et non fagades//ende al. fecho veynte e ocho días de jullio anno del nasçimiento//de nuestro señor iyesu xpo de myll e e quatroçientos e sesenta e çinco//annos, yo el Rey, yo iohan Ferrandes de Hermosylla secretario//del rey nuestro señor lo fis escrivyr por su mandado. A. archi//episcopus toletanus, al maestre de alcántara, al conde//don Álvaro, al conde de Benavente, cauriensis//...//..//alvalá Francisco Ferrandes de Sevylla//por virtud del qual dicho alvalá del dicho señor rey// fueron puestos e asentados al dicho arcediano//Diego botello los dichos xxx U [treinta 
mil] de quitaçión cada//...//.../[margen derecho: X II U de LXVI ¿? mrs.]//año et se han de librar desde XXVIII [28] días de jullio//[que es la fecha d: tachado] de dicho año de I U CCCC LXV [1465] fasta//en fin dél que le montan XII U DCLXVI mrs. castellanos [12.666] //los quales se le libraron en esta guysa...

\section{6, abril, 22. Salamanca.}

Nombramiento a través de un albalá de merced a Álvaro de Paz como miembro del Consejo Real del rey Alfonso de Ávila con 30.000 maravedíes de quitación.

\section{AGS, EMR, QC, leg. 2, 235r.}

...Don Álvaro de Pas dehan de la yglesia de Salamanca oydor de la abdençia del Rey nuestro señor. Mostró una alvalá del Rey nuestro señor fecho en esta guysa. Yo el rey mando a vos, los mis contadores mayores, que mi merçed e voluntad es que don Álvaro de Pas dehan de la iglesia de Salamanca del mi Consejo aya e tenga de mi de quitaçión en cada un año por del dicho mi Consejo treynta mill maravedíes por que vos mando que lo pongades e asentedes asý en los mis libros e nóminas de las quitaçiones que vosotros tenedes e libredes al dicho don Álvaro de Pas los dichos maravedíes este año de la fecha deste mi alvalá e dende en adelante en cada un año segund e quando librades a las otras personas de mi casa las quitaçiones que de mí tyenen e non fagades ende al fecho a veynte e dos días de abril año del nasçimiento de nuestro señor Jesucristo de mill e quatroçientos e sesenta e seys años. Yo el Rey. Yo Juan Fernandes de Hermosylla, secretario del Rey nuestro señor la fis escrivir por su mandado. Archiepiscopum Toletanum. El marqués de Villena. Registrada. Diego Sanches. Álvaro Fernandes García de Çibdad Real. Por virtud de la qual dicha alvalá del dicho señor Rey fueron puestos e asentados al dicho los dichos XXXv (30.000) de los quales le montan que ha de ver...

\section{0, 02 abril. Sevilla.}

Se prohíbe al maestrescuela de la Universidad de Salamanca el conocimiento del pleito sobre los frutos del arcedianazgo de Nájera, por distar más de dos dietas de la dicha ciudad y el obispado

\section{AGS, RGS, LEG, 1500-04, f. 109.}

Que el maestrescuela de Salamanca como jues conseruador no conosca de vn pleito porque está fuera de las dos dietas. Registrado Abril 1500.

Don Fernando e doña Ysabel, etc. A vos, el maestrescuela // del estudio e Vniversidad de la çibdad de Salamanca, // o a vuestro alcalde logartheniente e a cada uno e qualquier // de vos a quien esta nuestra carta fuere mostrada, o su traslado // signado de escriuano público: salud e gracia. Sepades // que Diego Fernandes de Mixanas, vecino de la çibdad de // Santo Domingo, nos fiso relación, etc., disiendo que // él ovo arrendado çiertos años los frutos e // rentas del Arçedianadgo de Nájera del arçe- // diano Juan Pereyra, arçediano que fue de Nájera, // e dis que como al dicho tiempo salieron los judíos // destos 
nuestros reynos, el diesmo de los quales dis // que pertenesçía al dicho Arçedianadgo, en la vega [?] // de Grañón e otros logares, e dis que porque no le // acudieron con los frutos e rentas de los dichos // terçios los dezmeros e reçebtores dello, él // no pudo pagar lo que asý montauan los dichos // terçios. E dis quel dicho arçediano, por fati- // gar al dicho Diego Fernandes de Minjanas, dis que // çedió e traspasó la abçión que tenía contra él // en Juan Pereyra, su hijo, que dis que es estudiante // en esta dicha çibdad, e dis que vos le avéis // fatigado, e fatigáis, por los dichos terçios, // proçediendo contra él por vuestras cartas e çensuras, // no lo pudiendo faser por ser, como dis que fue la dicha // çesión e traspasaçión, fraudolenta e porque, avn- // que no lo fuera, dis que la dicha çibdad de Santo Domingo, // donde el dicho Diego Fernandes de Mixanas bibe, // dista e está apartado de los confines del obispado // de Salamanca, a más y allende //de las dos dietas, dentro de las // quales podéys conosçer como conserva- // dor apostólico, conforme a la bula de nuestro // mui Santo Padre, y en caso que vos pertenesca, en lo // qual todo dis que él ha rescibido mucho agravio e // daño. E nos suplicó e pidió por merçed que sobre // ello proueyésemos de remedio con justicia, o como // la nuestra merçed fuese. Lo qual visto, etc., porque // vos mandamos que si la dicha çibdad de // Santo Domingo, donde el dicho Diego Fernan- // des de Mizanas es vesino, dista e está // apartado de Salamanca, amás y allende de // las dichas dos dietas, no vos entremetáys a // conosçer del dicho negocio e cabsa, ni de parte // alguna dello, a pedimiento del dicho Juan Pereyra // ni de otra persona alguna, e lo remitáys a los // jueses que dello pueden e deven conosçer, a los // quales mandamos que lo vean, e llamadas e oýdas / las partes a quien atañe, breuemente hagan cumplimiento // de justicia e si vos, el dicho mastrescuela, // o vuestro lugartheniente, en algo avéis proçedido // çerca de lo susodicho, vos mandamos que lo tor-// néys todo al punto e estado en que estaua antes // e al tienpo que dello conosçiésedes e de como esta // nuestra carta vos fuese leýda e notificada etc. // Dada en Seuilla, a dos días de abril de // mill e quinientos años. Johannes episcopus Ouetensis. // Filipus, dotor. Joannes licenciatus. Martinus, dotor. // Licenciatus Çapata Ferdinandus. Tello licenciatus. Yo, Juan Rodríguez, // escriuano de cámara etc. Castañeda.

\section{2, agosto, 21. Toledo.}

La reina solicita la intervención del cardenal de Santa Cruz para que se trate en Roma el problema de la provisión del deanato de Salamanca.

AGS, CCa, Ced. 6, 6-2, $n^{0} 1$.

...Muy reverendo in Christo padre Cardenal de Santa Cruz, mi muy caro e muy amado amigo//Yo, la Reyna de Castilla, de León, de Aragón, de Seçilia e Granada, etcétera, vos envío mucho a saludar//como aquel que mucho amo y presçio, e para quien querría que Dios diese tanta vida, salud e honrra quanta//vos mismo deseays. Resçibí vuestra carta sobre lo que nuevamente se ha proueýdo sobre lo del deanadgo//de la yglesia de Salamanca, y creo lo que por ella dezís, segund la confiança que yo de vos tengo.//Mas porque, como sabéys, la bulla de la coadjutoría de don Alonso de Castilla fue ganada 
a su-//plicaçión del Rey mi señor e mía, por paçificar las diferençias de aquella yglesia e poner-//la en buen horden, y la voluntad de nuestro muy Santo Padre en aquella primera bula fue que//avnque vacase el deanadgo de Salamanca por resi[g]nación simple o por qualquier dimisión//de don Áluaro de Paz, fecho en persona de qualquier cardenal, le ouiese don Alonso como //si vacase por muerte de don Áluaro de Paz, y con derogaçión de todo lo que después se prouey-//ese en contrario, por lo qual don Alonso tomó ya la posesión del deanadgo y se hizo por el//juez apostólico el proçeso contra los molestadores y perturbadores. Por ende, afectuosamente//vos ruego que con mucha diligencia trabajéis porque su Santidad quiera de nuevo re-//validar la bula de la coadjutoría, dada a suplicación del Rey mi señor e o e [tachado] mía, e//declarar aver vacado de nuevo el dicho deanadgo por la dicha resynaçión fecha en Cançe-//llería por el procurador de don Áluaro de Paz e con su poder, e que mande anular e reuocar//las bulas que después se dieron $<y$ las $>$ [interlineado] que adelante sobre aquello se diesen, pues es mucha//razón que lo [que] a nuestra suplicaçión está otorgado e proveýdo no lo aya su Santidad de//rebocar, y quando esto no se pudiese ansý fazer, lo que creo que se fará ponie-//do vos en ello, como creo que lo haréys por v [tachado] nuestro serviçio. Ruego vos mucho que//tengáys manera con las permutaçiones que se fisieren a fin de dar este deanadgo//a Juan Pereyra se desfagan, de manera que él se torne a su arçidianadgo de//Salamanca y el obispo cunpla con don Áluaro de Paz por su vida lo que//sea justo. Y pues todo esto se hizo por vuestra mano bien podéys vos//dar horden cómo se desfaga y torne al primer estado mayormente,//pues el obispo es contento de satisfaser a don Áluaro de Paz. E en se despa-//char en qualquier de estas maneras resibiré mucho plaser, y sobre todo//os fablará de mi parte el consejero Francisco de Rojas, mi embaxador, aquello vos//ruego que queráys poner en obra mi recado. Yn Cristo padre Cardenal mi muy//caro e muy amado amigo, Nuestro Señor en todos tiempos os aya// en su especial recomienda e guarda. De Toledo, a XXI de agosto de DII//años. Yo la Reyna. Cunchillos por secretario...

\section{2, noviembre. Salamanca.}

Se acuerda por el cabildo que, cuando el Señor disponga de Álvaro de Paz, se tañese la campana mayor de la iglesia.

\section{ACS, Cajón 70, AC 21, f. 31v.}

...Este dicho día e cabildo los dichos señores e deán e cabildo mandaron e acordaron que quando Dios dispusiese del señor don Álvaro de Paz deán que avýa seydo de la dicha yglesia que se taniese la campana grande y los otros abtos e solenidades que se suelen haser a los beneficiados de la dicha yglesia semejantes a su merçedes en tal caso de yr a su enterramiento al monesterio de la Trinidad fuera de la çibdad segund es de huso e de costumbre y el señor don Antonio de Paz arcediano de Nájera canónigo en la dicha yglesia que presente estava se obligó de pagar los florines contenidos en el estatuto en semejante causa como la mandaren los dichos señores e a su hordenamiento e etc. testigos dichos e Diego de Anaya notario 
1502, diciembre, 05. Salamanca.

Acta capitular que menciona las propiedades y rentas de Álvaro de Paz que habían vacado por su muerte.

ACS, Cajón 70, AC 21, f. 41v.

...con su jurediçión mero misto inperio y con todas sus aldeas y con todo su término redondo y con las terçias que son del dicho cabildo y con la torre y la casa de la paneras y la casa prinçipal del lugar y con [espacio en blanco] casas y con todo lo que le pertenesçe y el cabildo ha y tiene en él segund suele andar en renta eçebto el lugar de Valdelacalçada y las heredades de Boada y Çipéres y Pelarrodrigues que non entran en este arrendamiento, lo qual todo avýa vacado por muerte de Don Álvaro de Paz deán de la dicha yglesia que lo antes tenía y éste hera el postrimero cabildo en que se avýa de rematar, por ende pusiéronlo en renta en pública almoneda con condiçión que qualquiera que lo arrendase lo tomase a toda su ventura e caso fortuyto y por cosa que en ello acaesçiese non podiese dar ni poner descuento alguno al dicho cabildo salvo a fuego de las casas del y torre y panera y casa prinçipal de la dicha villa que no fuese obligado, otrosý con condiçión que lo toma mi signo que es a tal //[signo] en testimonio de verdad// Francisco Sanches, notario//...

\section{Bibliografía citada}

\section{Fuentes impresas}

Beltrán de Heredia, Vicente, Bulario de la Universidad de Salamanca 1218- 1549, (vol. I), ed. Universidad de Salamanca, Salamanca, 1966.

Beltrán de Heredia, Vicente, Bulario de la Universidad de Salamanca 1218-1549, (vol. II), ed. Universidad de Salamanca, Salamanca, 1966.

Beltrán de Heredia, Vicente, Cartulario de la Universidad de Salamanca 1218- 1600, (vol. II), ed. Universidad de Salamanca, Salamanca, 1970.

Documentación calagurritana del siglo XV. Archivo de la catedral, ed. Instituto de Estudios Riojanos, Eliseo Sainz de la Ripa y Ángel Ortega López, Logroño, 2004.

Los libros de las actas capitulares de la catedral de Salamanca (1298-1489), Raúl Vicente Baz (ed.), Archivo Catedral de Salamanca, Salamanca, 2008.

Los libros de las actas capitulares de la catedral de Salamanca (1489-1506), Raúl Vicente Baz (ed.), Archivo Catedral de Salamanca, Salamanca, 2016.

Llorente, Juan Antonio, Discursos Histórico-Canónicos sobre los Beneficios Patrimoniales de las Iglesias Parroquiales del Obispado de Calahorra y la Calzada, Pamplona, 1789. Náxara Ilustrada, fray Juan de SALAZAR (ed.), Patronato del Monasterio de Santa María la Real de Nájera, 1987.

SÁnchez Vaquero, José, Linajes de Salamanca, Salamanca: Universidad Pontificia de Salamanca, 2001. 
Solís, Alfonso de, Memorial de la Calidad i Serviçios de Don Cristóbal Alfonso de Solís i Enríquez, Madrid, Diputación de Barcelona, 1670.

Torres y TAPia, Alonso (frey), Crónica de la Orden de Alcántara, tomo II, Madrid: Imprenta de Gabriel Ruiz Ramírez, 1763.

\section{Bibliografía}

Asenjo GonzÁlez, María, "Acerca de los linajes urbanos y su conflictividad en las ciudades castellanas a fines de la Edad Media”, Clio \& Crimen, 6 (2009), pp. 52-84.

BARrios GarcíA, Ángel, "Repoblación de la zona meridional del Duero. Fases de ocupación, procedencias y distribución espacial de los grupos de repoblación", Studia Historica, Historia Medieval, 3 (1985), pp. 33-82.

Cantera Montenegro, Enrique, "La política de alianzas matrimoniales de los Reyes Católicos", Los reinos hispánicos ante la Edad Moderna, vol. I, 1995, pp. 465-502.

Catalán Martínez, Elena, "Derecho de patronato y el régimen beneficial de la Iglesia española en la Edad Moderna”, Hispania Sacra, LVI (2004), pp. 135-167.

Chacón JimÉnez, Francisco, “Familias y poderes: presentación”, Actas del VII Congreso internacional de la ADEH, Granada, 2004, pp. 1-8.

Diago Hernando, Máximo, "Estructuras familiares de la nobleza urbana en la Castilla bajomedieval: los doce linajes de Soria", Studia Historica. Historia Medieval, 10 (1992), pp. 47-71.

Díaz Bodegas, Pablo, "La diócesis de Calahorra en la Edad Media y su consolidación a la sombra del poder" Los espacios de poder en la España medieval (XII Semana de Estudios Medievales, Nájera, 2001), coord. José Ignacio de la Iglesia Duarte, José Luis Martín Rodríguez, 2002, pp. 459-482.

FERnÁNDEZ Conde, Francisco Javier, "Renacimiento urbano y religiosidad. Los cabildos de canónigos", Las sociedades urbanas en La España Medieval (XXIX Semana de Estudios Medievales de Estella, 2002), Pamplona, (Gobierno de Navarra), 2003, pp. 311-352.

GonzÁlez de Fauve, M. Estela; de Forteza, Patricia; Las Heras, Isabel J., "Los cargos eclesiásticos y religiosos como estrategia de recuperación de poder de los descendientes del Pedro I de Castilla”, En la España Medieval, 24 (2001), pp. 239-257.

Guijarro GonzÁlez, Susana, "Jerarquía y redes sociales en la Castilla medieval: la provisión de beneficios eclesiásticos en el cabildo de la catedral de Burgos: 1390-1441", Anuario de Estudios Medievales, 38/1 (2008), pp. 271-299.

IbÁÑEz Rodríguez, Santiago, "La diócesis de Calahorra a mediados del siglo XVI según el Libro de Visita del Licenciado Martín Gil”, Brocar, 16 (1998), pp. 135- 182.

LeCuOna, Manuel de, Toponimia riojana, Un préstamo del árabe a la toponimia de La Rioja y otras. Instituto de Estudios Riojanos, Logroño, 1953.

Lop OTín, M M José, "Las catedrales y los cabildos catedralicios de la corona de Castilla durante la Edad Media. Un balance historiográfico”, En la España Medieval, 23 (2003), pp. 371-404. 
Lop Otín, María José, "Los arcedianos en la sede toledana a fines de la Edad Media, Memoria ecclesiae, 27 (2005), pp. 389-407.

Lop Otín, María José, “Un grupo de poder a fines de la Edad Media: los canónigos de la catedral de Toledo", Anuario de Estudios Medievales, 35/2 (2005), pp. 635-670.

López Benito, Clara Isabel, Bandos nobiliarios en Salamanca, Centro de Estudios Salmantinos, Salamanca, 1983.

LóPEz Benito, Clara Isabel, "La oligarquía salmantina en los inicios de la Edad Moderna: actitudes ante la muerte", Investigaciones históricas: Época moderna y contemporánea, 12, Universidad de Salamanca, 1992, pp. 32-41.

Martín Benito, José Ignacio, "Lucha de bandos y beneficios eclesiásticos en los encastillamientos de Ciudad Rodrigo (1475-1520)", Studia Historica. Historia Medieval, 17 (1999), pp. 263-293.

Martín Martín, José Luis, El cabildo de la catedral de Salamanca (Siglos XII- XIII), Centro de Estudios Salmantinos, Salamanca, 1975.

Martín Martín, José Luis, “El poder económico de los canónigos medievales” en Historia 16, 61, 1981, pp. 55-60.

Monsalvo Antón, José María, Torres, tierras, linajes. Mentalidad social de los caballeros urbanos y de la élite dirigente en la Salamanca medieval (siglos XIII-XV) en Sociedades urbanas y culturas políticas en la baja Edad Media castellana, Ediciones Universidad, Salamanca, 2013.

Munsuri Rosado, $\mathrm{M}^{\mathrm{a}}$ Nieves, Perspectiva socio-económica del clero secular en la Valencia del Siglo XV (Tesis Doctoral). Universidad de Valencia, 2005.

Nieto Soria, J. Manuel; Ladero Quesada, M. Ángel, “Iglesia y sociedad en los siglos XIII al XV (ámbito castellano-leonés). Estado de la investigación”, En la España Medieval, 11 (1988), pp. 125-151.

Nieto Soria, José Manuel, "Enrique IV de Castilla y el pontificado”, En la España Medieval, 19 (1996), pp. 167-239.

Nieto Soria, José Manuel, "El pontificado de Martín V y la ampliación de la soberanía sobre la iglesia castellana”, En la España Medieval, 17 (1994), pp. 113-131.

Peláez Boismorand, Luis, Poder y movilidad social de los Paz, "señores de los Corrales” en el siglo XV, (Salamanca). (Tesis Doctoral). Universidad de Salamanca, 2014.

PÉrez GonzÁlez, Silvia María, "Los beneficios parroquiales: un acercamiento al estudio del clero secular", Hispania Sacra, LXIV (2012), pp. 497-523.

Quintanilla Raso, $M^{a}$ Concepción, "Reproducción y formas de transmisión patrimonial de los grandes linajes y casas nobiliarias en la Castilla tardomedieval", F. J. Lorenzo Pinar (ed.), La familia en la historia (Jornadas de Estudios Históricos), Universidad de Salamanca, Salamanca 2009, pp. 89-120.

RiverA, Antonio, La historia de Álava, Ed. Nerea, San Sebastián, 2003. 
Ruiz, Teófilo, Sociedad y Poder Real en Castilla. (Burgos en la Baja Edad Media), Ariel, Barcelona, 1981.

Sánchez Vaquero, José, Linajes de Salamanca, Universidad Pontificia de Salamanca, Salamanca, 2001.

SÁnchez Herrero, José, "Vida y costumbres de los componentes del cabildo catedral de Palencia a finales del siglo XV", Historia, Instituciones y Documentos, 3 (1976), pp. $485-532$.

Sánchez Herrero, José, Las diócesis del Reino de León: siglos XIV y XV, Centro de Estudios e Investigación "San Isidro”, León, 1978.

SÁnchez Herrero, José, “Amantes, barraganas y concubinas clericales”, Clio \& Crimen, 5 (2009), pp. 106-137.

SÁnchez Rodríguez, Marciano, "Orígenes de un conflicto: las provisiones en el cabildo catedralicio de Salamanca", Salamanca y su proyección en el mundo. Estudios históricos en honor de D. Florencio Marcos, Salamanca, 1992, pp. 355-365.

SANTAMARía LANCho, Miguel, "El cabildo catedralicio de Segovia como aparato de poder en el sistema político urbano durante el S. XV", Studia Historica. Historia Medieval, 8 (1990), pp. 47-77.

Santos Burgaleta, Manuel, "Extensiones de poder: Una propuesta de análisis en torno a la articulación de los espacios de poder. La valía del Dr. Talavera en Salamanca (1475-1521)", Espacios de poder: Cortes, Ciudades y Villas (S XVI-XVIII), vol. 2, 2002, pp. 73-92.

SARMiento Lasuén, José, “Alfonso de Quintanilla: Contador Mayor de Castilla”, Boletín de la Institución Fernán González, 117 (1951), pp. 713-724.

Villar y Macías, Manuel, Historia de Salamanca, libro V, desde el corregimiento del Almirante al señorío del príncipe Don Juan, reed. Graficesa, Salamanca, 1974.

Villarroel GonzÁlez, Óscar, "Servir al Rey en las ligas nobiliarias: eclesiásticos en las confederaciones políticas", Anuario de Estudios Medievales, 36/2 (2006), pp. 751-781. 